\title{
Learning Management System in Streamlining Learning through Seamless Learning Approach
}

\author{
Muchammad Eka Mahmud ${ }^{1}$, Faizatul Widat ${ }^{2}$, Anwar Fuadi ${ }^{3}$ \\ DOI: 10.35445/alishlah.v13i2. 787
}

Article Info

Keywords:

Learning Management

Sistem;

Learning;

Seamless Learning

Kata kunci:

Learning Management

Sistem;

Pembelajaran;

Seamless Learning

\begin{abstract}
This study aims to analyze and understand the learning management system in learning effectively through a seamless learning approach at Islamic Elementary School Nurul Anwar. This research uses a qualitative case study approach. The data collection technique is done through observation, interviews, and documentation. At the same time, the data analysis was carried out through the stages of data display, data reduction, and concluding. The results of the study indicate that learning system management through a seamless learning approach at SD Islam Nurul Anwar in making learning effective is carried out; 1) User-friendly, 2) User Interface, 3) Parental involvement, 4) learning with an online learning system, outside the network (luring), and mobile teachers (guling). This research has implications for the importance of teachers in utilizing various existing and available resources to make their learning effective as optimally as possible.
\end{abstract}

\begin{abstract}
Abstrak
Penelitian ini bertujuan untuk menganalisis dan memahami tentang learning manajemen sistem dalam mengefektifkan pembelajaran melalui pendekatan seamless learning di SD Islam Nurul Anwar. Penelitian ini menggunakan pendekatan kualitatif jenis studi kasus. Teknik pengumpulan datanya dilakukan melalui observasi, interview, dan dokumentasi. Sedangkan analisis datanya dilakukan melalui tahapan data display, data reduction dan penarikan kesimpulan. Hasil penelitian menunjukkan bahwa learning manajemen sistem melalui pendekatan seamless learning di SD Islam Nurul Anwar dalam mengefektifkan pembelajaran dilakukan; 1) User friendly, 2) User Interface, 3) Parental involvement, 4) pembelajaran dilaksanakan melalui daring, luar jaringan (luring) dan guru keliling (guling). Penelitian ini memberikan implikasi tentang pentingnya guru dalam memanfaatkan berbagai sumber daya yang ada dan dimilikinya dalam rangka mengefektifkan pembelajarannya dengan seoptimal mungkin.
\end{abstract}

\footnotetext{
${ }^{1}$ UIN Sultan Aji Muhammad Idris Samarinda, Indonesia

Email: ekamahmud.74@gmail.com

${ }^{2}$ Nurul Jadid University, Paiton, Probolinggo, East Java, Indonesia

Email: faizatulwidat59@gmail.com

3 Nurul Jadid University, Paiton, Probolinggo, East Java, Indonesia

Email: fuadianwar764@gmail.com
} 


\section{INTRODUCTION}

The COVID-19 pandemic has had a considerable impact on human life in various fields, economic, social, political, and educational (Ulfa, Surahman, \& Octaviani, 2020). From these various impacts, the Ministry of Education and Culture, the Ministry of Religion, the Ministry of Health, and the Ministry of Home Affairs provide new policies related to learning activities, health and safety of students, educators, families, and the community as a top priority in dealing with the Covid-19 pandemic (Suasthi, Bagus, \& Eka, 2020).

The government emphasized that it could not determine when the education sector would function optimally during the Covid-19 outbreak. In other words, the educational facilities will remain closed indefinitely (Satrianingrum \& Prasetyo, 2020). The government has taken steps to replace face-to-face learning in schools with learning activities at home. Home learning activities require distance learning or online activities to provide students with a meaningful learning experience. The distance education process bridges the gap between students and educators and is achieved through minimal technology and face-to-face meetings. (Sari \& Wisroni, 2020).

Based on the Child Protection Law Number 35 of 2014 concerning children's rights in a country, the media plays a role in disseminating information and educational materials that are beneficial to society, culture, and religious and health education by taking into account the best interests of children (Dakir, 2014). Providing distance education that crosses space and time allows students to study flexibly at different times and places and uses an increasingly complex variety of learning resources and technical media (Tohar, 2020).

Learning Management System (LMS) is the suitable media for learning activities during the pandemic at SD Islam Nurul Anwar, Paiton, Probolinggo, East Java, conducted online (Rabiman, Nurtanto, \& Kholifah, 2020). Furthermore, Chang (2020) said that LMS is software used to create web-based online learning materials and manage learning activities and results. In the LMS, some features can meet all user needs in learning (Khoa, Ha, Nguyen, \& Bich, 2020). These features include administration, material delivery, and easy access to reference sources, assessments, online exams, feedback collection, and communication, which provides online discussion forums, discussion mailing lists, and chat (Raharja, Prasojo, \& Nugroho, 2016).

Many types of research on learning management systems have been carried out, including; Raharja et al. (2016) said that the design of the LMS-based learning development model was based on the school's conditions, readiness, and needs. Wibowo et al. (2015) said that the development of a web-based LMS could improve student learning outcomes. Furthermore, Azis (2015) explained that the learning media based on the Learning Management System provides excellent benefits in making learning effective in schools

A learning management system is a learning system that is very useful in education (Dakir, 2017), especially in today's modern era. LMS is closely related to the seamless learning model. This learning model contains the concept of continuity and continuity in the learning process that occurs without time and space limits to create more optimal learning and keep up with the times.

Seamless learning as continuity in learning with various scenarios using mobile devices supports teachers and students in carrying out their learning activities (Durak \& Çankaya, 2018; Hamid et al., 2019), although some scenarios require them to be able to master all of them (Masduki, Suparman, \& Prayitno, 2017). Seamless learning consists of various scenarios where students are active, productive, creative, and can work together across different learning areas at any time and wherever the student is (Ulfa, 2017; Pecso \& Abadiano, 2020). Teachers can also increase the participation and involvement of students in the process of social interaction within the scope of education, both digital and non-digital (Otero et al., 2011).

Related to this seamless learning, in his research Ulfa (2014) argues that borderless learning emphasizes and is learner-centered with support to optimize learning. Dakir et al. (2021) explained that the seamless learning design could provide convenience and strong motivation for students in higher education. Berlin et al. (2020) explained that seamless learning could improve 
student learning outcomes. Furthermore, Maman et al. (2021) said that learning by using Google Classroom as part of a mobile seamless learning device can streamline learning, as well as the use of the Edmodo application, which, according to Mahmud et al. (2021), can provide a lot of experience and competence for students.

Departing from the several studies mentioned above, the learning management system with the seamless learning approach in this study are two concepts of learning strategies packaged into one activity to optimize learning during the COVID-19 pandemic. Combining these two concepts in learning becomes the novelty of this research to benefit subsequent learning activities.

Through LMS with a seamless learning approach, it is hoped that education that utilizes digital technology tools must be better and more optimal so that learning objectives can be achieved optimally. The existence of a learning management system to streamline student learning at Nurul Anwar Islamic Elementary School through seamless learning must be able to encourage them to be more active, creative, and innovative in obtaining as much knowledge as possible during the Covid-19 pandemic, where learning activities are not limited by space and time. Time and allows students to learn flexibly, whenever and wherever they are.

To streamline learning during the Covid-19 pandemic by combining two different approaches, the researchers focused on implementing learning management systems in facilitating learning with a seamless learning approach at Islamic Elementary School Nurul Anwar, Probolinggo, East Java.

\section{METHODS}

This research is qualitative research with the type of case study. The researcher tries to analyze and understand the learning management system in making learning effective with the seamless learning approach at Islamic Elementary School Nurul Anwar, Paiton, Probolinggo, East Java. This study consisted of people who understood the themes studied, namely the principal, viceprincipal, and teachers. To get a comprehensive understanding of the themes explored, the researchers conducted observational interviews and documentation of various existing activities.

The data analysis in this study was carried out circularly, starting from presenting all research findings on learning management systems in making learning effective with the seamless learning approach, both from interviews, observations and documentation. Then proceed with reducing research data through the selection and sorting of data by the research theme. The final step is concluding a formal research finding.

\section{FINDINGS AND DISCUSSION}

Implementation of learning management systems in streamlining learning with a seamless learning approach at SD Islam Nurul Anwar, Probolinggo, East Java is carried out in a planned and systematic manner by optimizing various resources owned by schools learning can run effectively and efficiently during the Covid-19 pandemic. The implementation of learning management systems with seamless learning in making learning effective are as follows;

\section{User friendly}

User friendly is a condition where individuals can use something easily and comfortably, whether using software, operating systems, or websites. The goal is only one, which is to make it easier for someone to find something or information that is important and display the results by his wishes. In today's learning activities, all devices or media that will be used must be user-friendly or easy to use, both by teachers and students.

Online learning is one way to overcome educational problems related to learning during the Covid-19 pandemic. Online learning, in this case, is understood as a method of learning activities that use an internet-based interactive model and a learning management system (LMS). Just like using Whatsapp, Zoom Meeting, Google Meet, Google Drive, etc. Online activities include web seminars, online courses, and all activities using the internet and computer networks. Online 
learning needs to create an atmosphere that supports learning at home. Students must learn effectively through video calls, discussions, and question and answer, but still have to socialize with other people, including family members, to hone social skills.

After the analysis of learners' need, the teacher decided to use simple and easy-to-use technological media in managing their learning during this pandemic, namely using the Whatsapp application to communicate with their students either through short messages, video recordings, or video calls. In addition, teachers also use the Google application to evaluate student learning activities.

As a teacher at Nurul Anwar Islamic Elementary School, WY said that teachers must choose the type of online learning application that is by the situation and condition of the students through various considerations, especially economic, social and geographical factors. Here, we use an application that is very simple and easily accessible to students and parents, namely the WhatsApp application, which is very familiar. It is due to avoid various obstacles that will be faced, such as the availability of devices owned by teachers or students, unstable internet network constraints, and so on.

FS said that the straightforward application in online learning during the pandemic at SD Islam Nurul Anwar is WhatsApp combined with Google. This application can be used as a medium that connects teachers and students in learning interactions. This application was chosen because this application is very familiar and can be used by all children. In addition to sending messages in text, this application can also send voice, photos, videos, document files, and other files. In addition, WhatsApp currently has a video call function that can accommodate up to 8 people at once.

One way to use WhatsApp for online learning at SD Islam Nurul Anwar is to create a particular WhatsApp group for each class. WhatsApp groups are considered as classrooms, and the group members are students and teachers as admins. In groups, students and teachers can communicate with each other, such as through discussion and participation. Voice messages or voice notes can be used as a way for teachers to teach lessons or to guide students. In addition, teachers can also send PowerPoints, videos, assignments, and so on.

The phenomenon above shows that teachers must be creative and innovative in carrying out their learning activities during the Covid-19 pandemic to become effective and efficient. These activities provide convenience for teachers and students in giving and receiving subjects well. Of course, the implementation of this is based on various considerations, especially considerations in economic, social, and geographical aspects.

\section{User Interface}

Whatsapp is one of the applications chosen by teachers and students in learning activities at Nurul Anwar Islamic Elementary School. This application is one of the technological developments that are very useful in communication and education and learning activities. As part of seamless mobile learning, WhatsApp is believed to bridge communication between teachers and students to streamline education during this pandemic, considering the features displayed are pretty exciting and varied. Through an exemplary user interface, it is hoped to arouse students' enthusiasm for learning with the various services.

According to WY, the implementation of online learning can be designed by the teacher himself, considering that the WhatsApp application has many features provided, both in the form of short messages, sending pictures and videos, and video calls. It depends on the teacher in presenting it to students. The voice note feature or voice message often used by teachers at SD Islam Nurul Anwar can be used for question and answer sessions. Teachers can use these voice notes to interact with students, thus making learning more active. This method is better than typing a message. Teachers can also determine how far students have digested the material because voice notes are sent directly, so what students say is a problem. 
In addition, the attachment feature can be used as an interactive learning medium. Teachers can make online learning fun with interactive learning media such as uploading videos, photos, and audio about the material presented. Teachers can create teaching materials with these media so that students do not feel bored. Teachers and students can also use the embed group chat feature to find class groups quickly. With this feature, the group chat will be at the top of the list, even if there are other incoming messages, where the group chat will not pile up at the bottom.

The features presented can provide a different learning atmosphere, where the teacher can control all student activities through the seamless learning car. This feature makes students more interactive and motivated in their learning to reduce boredom and boredom in education.

\section{Parental involvement}

Parental involvement in learning activities by using a learning management system through a seamless learning approach at SD Islam Nurul Anwar is carried out through; two-way communication, learning facilitator, communication technician, problem-solver which can be described as follows;

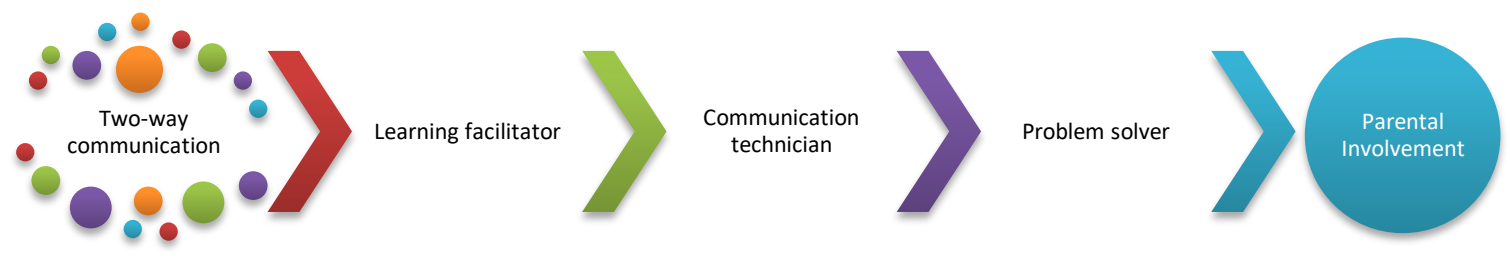

\section{Figure 1. Parental involvement}

Two-Way Communication is two-way communication in learning activities at Islamic Elementary School Nurul Anwar. It means two-way communication between the institution and the parents of students actively, through media intermediaries, so that a complete understanding of what is conveyed emerges. Learning that should be done face to face in the school environment now has to be carried out in the homes of each student.

FT said that communication with parents and students must be done wholeheartedly and confidently to be felt directly by students. The communication carried out has a deep meaning; there are guidance, direction, and instructions. FS said that communication with students during the COVID-19 pandemic was through the active participation of parents in teaching and learning activities at home. The teacher gives instructions via WhatsApp to parents; then, the parents accompany the child's learning process according to the direction of the teacher.

Learning Facilitator is a form of parent involvement in learning activities with system management learning through seamless learning at Islamic Elementary School Nurul Anwar. Learning facilitators, in this case, are interpreted as people who have an essential role in assisting children in understanding and solving various problems in online learning activities. FT said that the role of parents in online learning is vital because they are figures who can provide solutions to problems faced by children in their education.

Communication technician is the role of parents who are directly involved in providing technical communication services for their children in system management learning through seamless learning at Nurul Anwar Islamic Elementary School to get information from the teacher. According to FS, as people involved in providing technical services, parents must be active in communicating with teachers. They must be disciplined in seeking information related to learning activities provided by the teacher and actively provide information to their children at home.

According to WY, parents as technicians in communication must manage the information they receive from the teacher when accompanying children in learning to keep their data intact. Through this information, parents can convey the information they receive to their children. From this statement, it can be seen that parents, in this case, are given the task and responsibility to 
explain and describe the information and assignments provided by the teacher to their children so that children understand in doing the jobs they receive during the Covid-19 pandemic.

The problem solver, in this case, positions parents as someone who can solve learning problems faced by children during online learning. FT said that everything must be by its role in solving children's learning problems at SD Islam Nurul Anwar. The role of teachers, parents, and students collaborate in solving learning problems faced. WY said that parents as problem-solvers must position themselves as educators. In other words, all the tasks received by their children should not be done by parents, but parents are only in charge of guiding, directing, and providing answers if the child does not understand the task that must be done.

From this, it can be understood that parents are the main work partners for teachers in children's education. Therefore, intensive communication between parents and teachers is needed to avoid misperceptions and meanings in the communication process. Both must work hand in hand and help each other in children's education and learning activities, especially during the COVID-19 pandemic, through online learning. Parents, in this case, can provide direction and solutions to their children regarding learning that must be done and completed. Parents must play themselves as children's learning partners to help them overcome existing problems together.

\section{System Model}

During the Covid-19 period, teachers must continue their education in schools as educators and are required to be creative, innovative, and act as learning facilitators, especially in online learning. It has a significant impact on the strategies used by teachers at SD Islam Nurul Anwar in making their learning effective, where teachers try to combine their education between online, offline (luring), and mobile teachers (guling). The system model referred to here is a learning system used by teachers in making their learning effective through the use of a learning management system with a seamless learning approach.

According to FS, learning through e-learning with a seamless learning approach is a learning in which the learning transformation process between students and educators uses easy and simple information and communication technology. In times of a pandemic like this, the application of online learning certainly requires effective and appropriate media according to the conditions or abilities of students at Nurul Anwar Islamic Elementary School. According to him, Whatsapp is a choice of learning media that is very appropriate when compared to other online learning media; this is because WhatsApp is a straightforward application, easy to operate.

Learning using this media is a form of learning management system used by teachers in making learning effective. Teachers use simple media, namely WhatsApp, as part of seamless learning that is easy to use for students and their guardians as their companions.

Offline learning or outside the network is learning that does not use the internet. In this case, the teacher holds face-to-face meetings with students in limited groups to avoid the risk of spreading the Covid-19 virus. In this case, the teacher invites students to study somewhere or make family visits to get material that cannot be digested when online learning occurs. This learning model is intended to complement the various shortcomings and weaknesses of online education carried out by teachers.

FT explained that house-to-house visits are one of the strategies implemented by teachers to optimize learning outcomes, considering that many students and their parents are not satisfied with the results of online learning. Furthermore, FS said that the teacher's home visit activity was, of course, through parental approval, and the school would prepare a parent availability form by the home visit learning method. The technique of implementing home visits through small groups carried out at Nurul Anwar Islamic Elementary School is carried out using teachers conducting daily home visits to 1 or 3 children so that the learning process at home reaches the best and more optimal conditions. Before starting the home visit, the teacher will arrange a schedule and notify parents by telephone. If parents have a schedule limit determined by the teacher, parents may change the plan. 
Furthermore, teachers at the Nurul Anwar Islamic Elementary School in Kotaanyar used the Guling (mobile teacher) strategy to provide optimal service to their students during the Covid-19 pandemic. In this case, the teacher tries to gather up to 10 students for face-to-face learning by utilizing public places, such as prayer rooms or mosques, to provide additional education and solve problems faced by students during online learning.

This activity complements the learning management system activities through a seamless learning approach. The learning has a weakness, namely the limited communication between teachers and students when online learning occurs, causing the teacher's explanations to be less accepted and understood by students. In addition, students also feel bored with complete online learning. To overcome this, the teacher took the initiative to hold guling learning to complement the learning management system design through a seamless learning approach.

WY explained that this kind of learning program had received approval and permission from the government to provide extra services to students, considering that complete online learning has many problems and is considered less than optimal. According to FT, SD Islam Nurul Anwar held online learning before using the home visit method. However, some students and their parents are not satisfied with this method, especially those who live in remote areas and do not have the supporting facilities to participate in online learning activities due to limited cellphones and signal limitations in some areas. Therefore, the bolster learning design was chosen to provide additional learning services to students during the covid-19 pandemic, with a note using a health protocol.
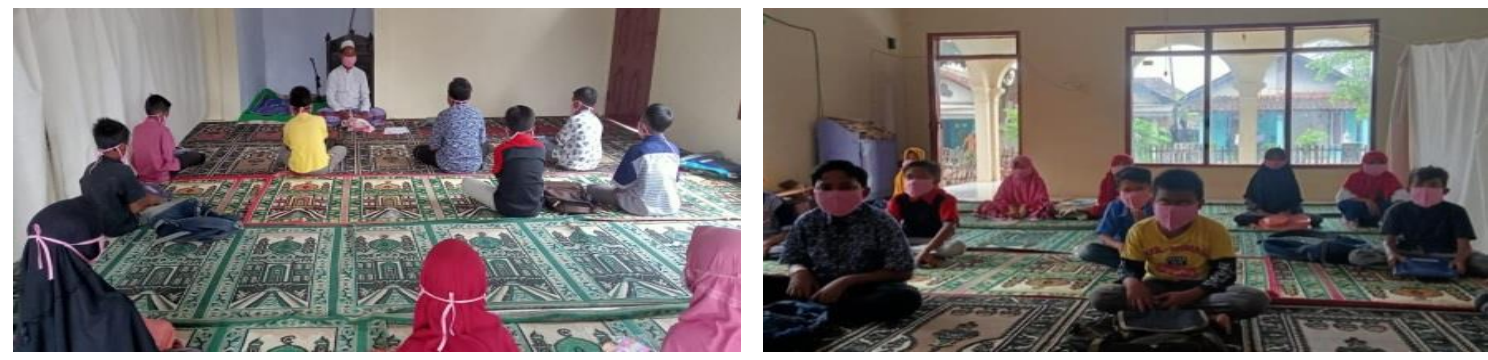

Figure 2. Guling learning model

The mobile teacher consists of visiting teachers and students who can accommodate up to 10 children. Using public places such as prayer rooms or mosques, teachers and students can learn face-to-face with complete health protocols. For the study schedule for each rolling course, students will get a specific topic once a week. The study time is from 08.00 to 10.00 WIB. Under the guidance of a rotating teacher (travel teacher), students can obtain material directly from the teacher to better understand the material they do not know when learning online and get additional direct learning.

In mitigating Covid-19, the government issued a policy regarding online learning or learning from home (Mustajab \& Fawa'iedah, 2020; Fajri et al., 2021; Rahman \& Subiyantoro, 2021). Tutoring at home is part of the government's policy plan regarding physical distancing to prevent the spread of the coronavirus or Covid-19 (Mujiansyah \& Rafsanjani, 2020; Rahman \& Subiyantoro, 2021; Suwidiyanti \& Anshori, 2021).

Primary school children's education is one of the sectors hardest hit by this epidemic. So far, the Ministry of Education and Culture has not allowed other local governments to open schools and carry out learning activities except in the yellow and green zones (Adham \& Mahmudah, 2021; Rifqi, 2021). To fulfill the right of students to obtain educational services during the Covid-19 period, the learning process is carried out by implementing learning from home using a learning management system by the regulations of the Ministry of Education and Culture, guidelines for implementing learning from home during the Covid-19 emergency (Russamsi et al., 2020; Wicaksana, E.J., 2020; Monaziroh \& Choirudin, 2021). 
Rapid advances in information technology support the implementation of electronic-based learning (e-learning). Learning management systems with a seamless learning approach has many advantages, including students sharing information and accessing learning materials at any time and carrying out evaluations that can measure students' conceptual understanding. (Taufiqurrochman, Muslimin, Rofiki, \& ABAH, 2020). With conditions like this, students are expected to strengthen their understanding of the concept of learning material (Akram \& Muhammad Khan, 2020). Elearning can train students' independence in technical and experience using it (Zelinskiy, 2020). In addition, a learning management system with a seamless learning approach can also assist teachers in monitoring student activity with various assignments given (Wibowo et al., 2015; Das et al., 2020).

Basically, in a learning management system, through a seamless learning approach, students have the opportunity to collaborate (Pecso \& Abadiano, 2020) and interact in various forms with peers, learning resources, and the physical world (Wong, 2012). The management of the learning management system through the seamless learning approach includes distributing subject matter that allows interaction between teachers and students. Students can see assignments and available learning modules with a learning management system through a seamless learning approach. Make it easier for students to understand the learning material through the module. Students can also work immediately by taking assignments and tests from the teacher concerned, and they can also discuss with their friends and teachers. In addition, interactions are also carried out through virtual worlds (Fahyuni, Wasis, Bandono, \& Arifin, 2020).

The principle of learning from home using a learning management system through this seamless learning approach is that students can access learning materials and resources regardless of time and place (Wahid et al., 2020; Hasnine et al., 2020). This learning activity is expected to support the distance learning process and facilitate the distribution of material to students (Harling, 2020). Therefore, during the Covid-19 pandemic, the learning process is usually carried out face-toface with teachers or teachers, and students in schools cannot be carried out. For this reason, teachers must also prepare learning tools so that students can study at home well. This situation makes teachers have to change their teaching strategies (Baharun, 2015). During distance learning, appropriate teaching methods and teacher behaviors and attitudes must be used to manage the teaching process (Dormalin, Liufeto, \& Cornelis, 2020). All of this is to provide students with learning opportunities that are not limited to space and time during the Covid-19 emergency (Mulenga \& Marbán, 2020). The situation of students and teachers who cannot meet in-person to maintain social and physical distance is a reason to learn through online learning (Rahmawati \& Dewi, 2019; Jamaludin et al., 2020).

\section{CONCLUSION}

In general, Nurul Anwar Islamic Elementary School has implemented a learning management system to streamline learning with a seamless learning approach to break the chain of the spread of the Covid-19 virus. From the results of this study, it can be concluded that the learning management system with a seamless learning approach can run effectively when there is solid cooperation between parents, teachers, and students. In addition, the concept will be optimal when combined with other learning model approaches, namely the offline and bolster model, which is intended to overcome various problems and problems faced by teachers and students during complete online learning.

This research focuses on educational institutions in rural areas with many limitations and resource constraints, so they have to fight hard to learn during the Covid-19 pandemic. The results of this study cannot be generalized to all educational institutions in Indonesia, thus providing opportunities for further research based on different situations and conditions, which are expected to complete this research.

\section{REFERENCES}

Adham, A. S., \& Mahmudah, F. N. (2021). “Art and Culture” Learning Management for Students' 
Increased Achievement During the Covid-19 Pandemic. Al-Tanzim: Jurnal Manajemen Pendidikan Islam, 5(1), 106-114. https://doi.org/10.33650/al-tanzim.v5i1.1904

Akram, M., \& Muhammad Khan, A. (2020). Exploring E-Leadership of Principals: Increasing School Effectiveness by Learning Management System. Journal of Education \& Social Sciences, 8(1), 15-30. https://doi.org/10.20547/jesso812008102

Azis, A. A. (2015). Pengembangan Media E-Learning Berbasis LMS Moodle pada Matakuliah Anatomi Fisiologi Manusia. Jurnal Pendidikan Biologi, 7(1), 1-8.

Baharun, H. (2015). Penerapan Pembelajaran Active Learning untuk Meningkatkan Hasil Belajar Siswa di Madrasah. Pedagogik; Jurnal Pendidikan, 2(2).

Berlin, M., Ausi, A., \& Abdillah, M. L. (2020). Penggunaan Strategi Seamless Learning pada Penguasaan Kosa Kata Siswa. Jurnal Pendidikan, 29(3), 197-202. Retrieved from http://journal.univetbantara.ac.id/index.php/jp/article/view/983

Chng, L. K. (2020). Face-to-Face Tutorials, Learning Management System and WhatsApp Group: How Digital Immigrants Interact and Engage in E-learning? Malaysian Online Journal of Educational Technology, 8(1), 18-35. https://doi.org/10.17220/mojet.2020.01.002

Dakir. (2014). Manajemen Layanan Pendidikan Siswa Berkebutuhan Khsusus Prespektif Religious, Filosofis, Yuridis dan Historis. Yogyakarta: K-Media.

Dakir. (2017). Manajemen Berbasis Sekolah. Yogyakarta: K-Media.

Dakir, Muali, C., Zulfajri, \& Muali, C. (2021). Design Seamless Learning Environment in Higher Education with Mobile Device Design Seamless Learning Environment in Higher Education with Mobile Device. Journal of Physics: Conference Series 1899, 1899, 1-5. https://doi.org/10.1088/1742-6596/1899/1/012175

Das, S. W. H., Halik, A., Iman, B., \& ... (2020). Developing a Sociocultural Approach in Learning Management System through Moodle in the Era of the Covid-19. International Journal of Innovation, Creativity and Change, 13(7), 941-958.

Dormalin, T., Liufeto, M. C., \& Cornelis, Y. Y. (2020). Implementasi Belajar Dari Rumah (Bdr) Bagi Tenaga Pendidik Untuk Meningkatkan Profesionalitas Mengajar Didaerah Terpencil. Prosiding Hasil Pengabdian Kepada Masyarakat, (Hapemas 2), 359-367.

Durak, G., \& Çankaya, S. (2018). Seamless Learning: A Scoping Systematic Review Study. Journal of Education and E-Learning Research, 5(4), 225-234. https://doi.org/10.20448/journal.509.2018.54.225.234

Fahyuni, E. F., Wasis, Bandono, A., \& Arifin, M. B. U. B. (2020). Integrating islamic values and science for millennial students' learning on using seamless mobile media. Jurnal Pendidikan IPA Indonesia, 9(2), 231-240. https://doi.org/10.15294/jpii.v9i2.23209

Fajri, Z., Muali, C., \& Farida, L. (2021). Student's Learning Motivation and Interest ; The Effectiveness of Online Learning during COVID-19 Pandemic. Journal of Physics: Conference Series, 1899, 1-10. https://doi.org/10.1088/1742-6596/1899/1/012178

Hamid, A., Setyosari, P., Kuswandi, D., \& Ulfa, S. (2019). The Implementation of Mobile Seamless Learning Strategy in Mastering Students' Concepts for Elementary School. Journal for the Education of Gifted Young Scientists, 7(4), 967-982. https://doi.org/10.17478/jegys.622416

Harling, V. N. Van. (2020). Analisis Hubungan Kedisiplinan Belajar Dari Rumah ( Bdr ) Dengan Prestasi Belajar Kimia Siswa Selama Masa Pandemi. Soscied, 3(2), 1-6.

Hasnine, M. N., Ogata, H., Akçapınar, G., Mouri, K., \& Kaneko, K. (2020). Closing the experiential learning loops using learning analytics cycle: Towards authentic experience sharing for vocabulary learning. International Journal of Distance Education Technologies, 18(3), 78-98. https://doi.org/10.4018/IJDET.2020070105

Jamaludin, T, R., Gunawan, \& E, P. (2020). Pembelajaran Daring Masa Pandemi Covid-19 Pada Calon Guru: Hambatan ,Solusi dan Proyeksi. Jurnal Cakrawala Pendidikan, 67(2), 1-10.

Khoa, B. T., Ha, N. M., Nguyen, T. V. H., \& Bich, N. H. (2020). Lecturers' adoption to use the online Learning Management System (LMS): Empirical evidence from TAM2 model for Vietnam. Hcmcoujs - Economics and Business Administration, 10(1), 3-17. https://doi.org/10.46223/hcmcoujs.econ.en.10.1.216.2020

Mahmud, E., Rozi, F., Syakroni, A., Muali, C., \& Widad, R. (2021). The Effect of Using Edmodo Application on Students ' Mastery Skill of Technology. Journal of Physics: Conference Series, 1899, 1-6. https://doi.org/10.1088/1742-6596/1899/1/012157

Maman, Witarsa, R., \& Ainin, D. T. (2021). Google Classroom as a Distance Learning Tool during a Pandemic Google Classroom as a Distance Learning Tool during a Pandemic. Journal of 
Physics: Conference Series PAPER, 1899, 1-5. https://doi.org/10.1088/17426596/1899/1/012176

Masduki, L. R., Suparman, S., \& Prayitno, E. (2017). Prototype of media mobile learning with ethnomatematic model on geometry college. Proceeding of ICMSE, (2), 104-111.

Monaziroh, A., \& Choirudin, C. (2021). The Development Design of Curriculum 2013 for Fiqih Learning Through a Humanistic Approach. Al-Tanzim: Jurnal Manajemen Pendidikan Islam, 5(1), 140-153. https://doi.org/10.33650/al-tanzim.v5i1.1675

Mujiansyah, R. A., \& Rafsanjani, M. A. (2020). Pengaruh Belajar Dari Rumah ( BDR ) dan Penggunaan Media LKS Berbasis Online Terhadap Hasil Belajar Ekonomi di Kelas X SMA Negeri 1 Suko Tuban. JUPE, 1(1), 20-33.

Mulenga, E. M., \& Marbán, J. M. (2020). Is COVID-19 the Gateway for Digital Learning in Mathematics Education? Contemporary Educational Technology, 12(2), 1-11. https://doi.org/10.30935/cedtech/7949

Mustajab, M., \& Fawa'iedah, Z. (2020). Adapting to Teaching and Learning During Covid-19: A Case of Islamic School's Initiative of Self-regulated Learning. Nadwa, 14(2), 241-264. https://doi.org/10.21580/nw.2020.14.2.6515

Otero, N., Milrad, M., Rogers, Y., Santos, A. J., Veríssimo, M., \& Torres, N. (2011). Challenges in designing seamless-learning scenarios: Affective and emotional effects on external representations. International Journal of Mobile Learning and Organisation, 5(1), 15-27. https://doi.org/10.1504/IJMLO.2011.038689

Pecso, G. L., \& Abadiano, M. N. (2020). Seamless learning in a decongested curriculum: A paradigm shift theory. Journal of Critical Reviews, 7(17), 1942-1951. https://doi.org/10.31838/jcr.07.17.241

Rabiman, R., Nurtanto, M., \& Kholifah, N. (2020). Design and development E-learning system by learning management system (Lms) in vocational education. International Journal of Scientific and Technology Research, 9(1), 1059-1063.

Raharja, S., Prasojo, L. D., \& Nugroho, A. A. (2016). Model Pembelajaran Berbasis Learning Management System dengan Pengembangan Software Moodle di Sekolah Menengah Atas. Jurnal Pendidikan, 41(1), 34-44.

Rahman, A., \& Subiyantoro, S. (2021). The Leardership Role of School Principals in Online Learning During the Covid-19 Pandemic. Al-Tanzim: Jurnal Manajemen Pendidikan Islam, 5(1), 165175. https://doi.org/10.33650/al-tanzim.v5i1.1805

Rahmawati, M. C., \& Dewi, N. D. L. (2019). Penanaman Perlaku Hidup Bersih dan Sehat di PAUD Atmabrata, Cilincing, Jakarta. Jurnal Mitra, 3(1), 41-49.

Rifqi, A. (2021). Regional Based Kkn Management: Toward Freedom of Learning During the Covid19 Pandemic. Al-Tanzim: Jurnal Manajemen Pendidikan Islam, 5(1), 95-105. https://doi.org/10.33650/al-tanzim.v5i1.1866

Russamsi, Y., Hadian, H., \& Nurlaeli, A. (2020). Pengaruh Kepemimpinan Kepala Sekolah Dan Peningkatan Profesional Guru Terhadap Kinerja Guru Di Masa Pandemi Covid-19. MANAGERE: Indonesian Journal of Educational Management, 2(3), 244-255. https://doi.org/10.52627/ijeam.v2i3.41

Sari, N. Y., \& Wisroni, W. (2020). The Urgency of Parental Guidance for Youth Education in the Belajar Dari Rumah (BDR) Era. SPEKTRUM: Jurnal Pendidikan Luar Sekolah (PLS), 8(3), 309-321. https://doi.org/10.24036/spektrumpls.v8i3.109565

Satrianingrum, A. P., \& Prasetyo, I. (2020). Persepsi Guru Dampak Pandemi Covid-19 terhadap Pelaksanaan Pembelajaran Daring di PAUD. Jurnal Obsesi: Jurnal Pendidikan Anak Usia Dini, 5(1), 633-640. https://doi.org/10.31004/obsesi.v5i1.574

Suasthi, I. G. A., Bagus, I., \& Eka, P. (2020). Membangun Karakter “ Genius ” Anak Tetap Belajar Dari Rumah Selama Pandemi Covid - 19 Pada Sekolah Suta Dharma Ubud Gianyar. Cetta:Jurnal Ilmu Pendidikan, 3(3), 431-451.

Suwidiyanti, \& Anshori, I. (2021). School Strategy to Build Students' Social Solidarity During Online Learning. Al-Tanzim: Jurnal Manajemen Pendidikan Islam, 5(1), 28-41.

Taufiqurrochman, R., Muslimin, I., Rofiki, I., \& ABAH, J. A. (2020). Students' Perceptions on Learning Management Systems of Arabic Learning through Blended Learning Model. Jurnal Al-Bayan: Jurnal Jurusan Pendidikan Bahasa Arab, 12(1), 22-36. https://doi.org/10.24042/albayan.v12i1.5276

Tohar, M. (2020). Pelaksanaan belajar dari rumah (bdr) pada sekolah menengah Atas. Historis: 
Jurnal Kajian, Penelitian \& Pengembangan Pendidikan Sejarah, 5(2), 166-170.

Ulfa, S. (2017). "Mobile Seamless Learning" Sebagai Model Pembelajaran Masa Depan. JINOTEP (Jurnal Inovasi Dan Teknologi Pembelajaran) Kajian Dan Riset Dalam Teknologi Pembelajaran, 1(1), 11-19. https://doi.org/10.17977/umo31v1i12014p011

Ulfa, S., Surahman, E., \& Octaviani, H. I. (2020). Mobile Seamless Language Learning Framework to Improving Students' Speaking Skills for Junior High Students during Pandemic Convid-19: A Case Study in Indonesian Context. Atlantis Press, 508, 497-500. https://doi.org/10.2991/assehr.k.201214.284

Wahid, A. H., Najiburrahman, Rahman, K., Faiz, Qodriyah, K., Hambali, ... Muali, C. (2020). Effectiveness of Android-Based Mathematics Learning Media Application on Student Learning Achievement. Journal of Physics: Conference Series, 1-7. https://doi.org/10.1088/17426596/1594/1/012047

Wibowo, A. T., Akhlis, I., \& Nugroho, S. E. (2015). Pengembangan LMS (Learning Management System) Berbasis Web untuk Mengukur Pemahaman Konsep dan Karakter Siswa. Scientific Journal of Informatics, 1(2), 127-137. https://doi.org/10.15294/sji.v1i2.4019

Wicaksana, E.J., A. P. (2020). Efektifitas Pembelajaran Menggunakan Moodle Terhadap Motivasi Dan Minat Bakat Peserta Didik di Tengah Pandemi Covid 19. EduTeach, 1(2), 117-124. https://doi.org/https://doi.org/10.37859/eduteach

Wong, L. H. (2012). A learner-centric view of mobile seamless learning. British Journal of Educational Technology, 43(1), 19-23. https://doi.org/10.1111/j.1467-8535.2011.01245.x

Zelinskiy, S. (2020). Analysis of the possibilities of the moodle learning management system for organization of distance learning in the conditions of the university. ScienceRise: Pedagogical Education, 5(38), 33-36. https://doi.org/10.15587/2519-4984.2020.213100 